\title{
Hepatitis B virus genotypes in Southeast Brazil and its relationship with histological features
}

\author{
Leticia Cancella Nabuco ${ }^{1 /+}$, Francisco Campello do Amaral Mello ${ }^{2}$, \\ Selma de Andrade Gomes², Renata Mello Perez¹, Jorge André Segadas Soares', \\ Henrique Sérgio Moraes Coelho', Cristiane Alves Villela Nogueira ${ }^{1}$
}

${ }^{1}$ Divisão de Histopatologia, Hospital Universitário Clementino Fraga Filho, Universidade Federal do Rio de Janeiro, Rio de Janeiro, RJ, Brasil ${ }^{2}$ Laboratório de Virologia Molecular, Instituto Oswaldo Cruz-Fiocruz, Rio de Janeiro, RJ, Brasil

Data concerning the relationship between hepatitis B virus (HBV) genotypes and liver histology are scarce. The aim of this study was to compare $H B V$ non- $B$ and non-C genotypes according to demographic features, clinical status, HBV-DNA levels and liver histology in Rio de Janeiro. One hundred twenty one consecutive chronic HBVinfected patients were enrolled during two-year period and data were prospectively collected. Sera were tested for $H B V$ genotyping using restriction fragment length polymorphism. Liver biopsy was obtained from patients with either increased alanine aminotransferase (ALT) or HBV-DNA levels. Genotype A was the most common, found in $82(68 \%)$ patients, followed by $F$ in $19(15 \%)$, D in $17(14 \%), B$ in one (1\%) and C in two (2\%). There was no association between HBV genotypes $A, D$ and $F$ and gender $(p=0.37)$, age $(p=0.78)$, race $(p=0.22)$, mode of infection ( $p$ $=0.94), H B$ " $e$ " antigen status $(p=0.37)$ and HBV-DNA levels $(p=0.47)$. The ALT levels were lower in genotype $D$ $(75 \%)$ compared with $A(47 \%)$ and $F(55 \%)(p=0.05)$. Liver biopsy showed lower inflammation [histological activity index $(H A I)=4]$ and fibrosis $(F)(=0)$ scores in genotype D than in genotypes $A$ (HAI = 5, $p<0.001 ; F=2, p$ $=0.008)$ or $F(H A I=5, p=0.009 ; F=2, p=0.01)$. Genotype $A$ was the most prevalent in chronic HBV-infected patients and genotype D patients presented with less intense liver disease.

Key words: HBV genotypes - hepatitis B - HBV-DNA - liver histology - HBeAg - ALT

Infection with the hepatitis B virus (HBV) remains a very important disease, with 400 million people chronically infected and 50 million new cases diagnosed annually (WHO 2000).

Most of the information on the clinical significance of HBV genotypes has been based on studies from Asia countries and is restricted to comparisons between genotypes B and C (Lindh et al. 1999, Chu et al. 2002, Kao et al. 2002, Kobayashi et al. 2002, Sakugawa et al. 2002, Wai et al. 2002, Lee et al. 2003, Nakayoshi et al. 2003, Sumi et al. 2003). Few studies have evaluated the role of genotypes in non-Asian population and the infection outcomes (Mayerat et al. 1999, Sanchez-Tapias et al. 2002, Thakur et al. 2002, Chu et al. 2003, Gandhe et al. 2003, Kumar et al. 2005, Halfon et al. 2006, Madan et al. 2009).

In Brazil, the prevalence of chronic HB infection varies greatly owing to its continental dimensions with a great ethnic diversity. The majority of Brazilian regions, which includes Rio de Janeiro (RJ), in Southeast Brazil, has a low prevalence of chronic HBV infection, with a positivity for $\mathrm{HB}$ surface antigen (HBsAg) less than $1 \%$ (Pereira et al. 2009), in contrast to a higher endemicity, up to $3 \%$, at the Amazonian Basin (Viana et al. 2005). Mello et al. (2007) among others have already shown that genotype $\mathrm{A}$ is the most prevalent genotype in Brazil

+ Corresponding author: leticia.nabuco@terra.com.br Received 28 November 2011

Accepted 22 March 2012 followed by genotypes D and F (Araujo et al. 2004, Viana et al. 2005, Ribeiro et al. 2006).

So far, the association between genotypes non-B and non- $\mathrm{C}$ and severity of liver disease is unclear. The aim of this study was to compare the non-B and non-C genotypes in RJ, according to demographic features, clinical status, serum HBV-DNA levels and liver histology.

\section{PATIENTS, MATERIALS AND METHODS}

This is a cross-sectional study of adults with chronic HBV infection in RJ. Consecutive chronic HBV-infected patients seen in Federal University of Rio de Janeiro, during a two-year period from January 2007-January 2009, were enrolled. This is the main reference centre for the study of HB in RJ. Inclusion criteria were chronic HBV infection defined as presence of HBsAg for more than six months and detectable serum HBV-DNA levels. Patients previously treated or ongoing antiviral treatment were excluded. For the comparative analysis, patients with hepatitis Delta, human immunodeficiency virus (HIV) and hepatitis $\mathrm{C}$ virus (HCV) co-infection were also excluded.

The study was approved by the Research Ethical Committee and eligible patients were asked to sign a written consent form before participating in this study.

Demographic, clinical and laboratorial data were collected during clinical visits. Demographic data included gender, age and race. Clinical information included presumed source of infection (vertical, horizontal and unknown). Laboratory data included serum alanine aminotransferase (ALT) levels, HBsAg, HB "e" antigen (HBeAg) status, HBV-DNA levels, HBV genotyping, anti-HCV, anti-HDV, anti-HIV and liver histology. 
ALT levels - Three ALT values were performed at two months intervals. Based on ALT values, patients were classified as follow: normal ALT $[\leq 1 \times$ upper limit of normal values (ULN) in the 3 determinations] or elevated $\operatorname{ALT}(>1 \mathrm{x}$ ULN in at least 1 of the 3 determinations).

Determination of serological markers - The serologic profile was evaluated based on the detection of $\mathrm{HBsAg}$, HBeAg, anti-HBe, anti-HCV and anti-HIV by enzyme immunoassay (Abbott, North Chicago, IL, USA). Antibody to hepatitis D virus was tested with enzyme-linked immunosorbent assay (Abbott, Abbott Park, IL, USA).

Quantitative detection of serum $H B V-D N A$ - Serum HBV-DNA levels were determined by a sensitive PCR quantitative method, Cobas Taqman, HBV assay (Roche) (range 29-110,000,000 IU/mL).

$H B V$ genotyping - HBV genotyping was determined by a restriction fragment length polymorphism (RFLP). Serum HBV-DNA was extracted and amplified using polymerase chain reaction (PCR) with pre-S and $\mathrm{S}$ gene primers. The PCR products containing genotype-specific regions were digested by restriction enzymes and the fragments were submitted to electrophoresis on agarose gel stained with ethidium bromide (Roche Molecular Biochemicals, Mannheim, Germany). The patterns of DNA fragments were then examined under ultraviolet light and compared with published patterns to ascertain HBV genotypes (Mizokami et al. 1999).

Histological analysis - Liver biopsy was obtained from patients with either increased ALT or HBV-DNA levels $>2,000 \mathrm{IU} / \mathrm{mL}$ or both. The histological lesions were graded according to the classification proposed by Ishak et al. (1995). Stage of fibrosis (F) and grade of inflammation [histological activity index (HAI)] were converted into binomial variables of advanced fibrosis (stage 3-6) vs. mild fibrosis (stage 0-2) and moderate/ severe inflammation (grade 7-18) vs. mild inflammation (grade 0-6). The diagnosis of liver cirrhosis was defined when the staging score of the Ishak system was $\geq 5$.

Statistical analysis - Data were analyzed with the SPSS for Windows version 11 (SPSS, Inc, Chicago, IL, USA). Numerical variables were expressed as mean and standard deviation and the median was used when the variable did not show a Gaussian distribution. Categorical variables were reported as absolute and relative frequency. The $\chi 2$ test and Fisher exact test were used for comparison of the categorical variables. Numerical variables were compared by the Student $t$ test, Mann-Whitney and Kruskal-Wallis tests. A level of significance of $0.05(\mathrm{a}=5 \%)$ was adopted.

\section{RESULTS}

Demographic, clinical, biochemical and virological characteristics - The main characteristics of the 121 patients are provided in Table I.

The study population included 89 (74\%) male patients and mean age was $38.3 \pm 12.8$ years (range $12-68$ ). The proportion of race in the study was $50 \%$ of white patients, $47 \%$ of black and only 3\% were Asian. The presumed mode of infection was known in $68(56 \%)$ patients; $36 \%$ were presumed to have acquired HBV infection through sexual or parenteral exposure and $20 \%$ with a history of maternal-infant route. ALT levels were elevated in 62 (51\%), the median value was $0.9 \times$ ULN.

Among the 121 patients with chronic HBV infection enrolled, eight (6\%) were HBV-HIV coinfected patients, all of them currently receiving antiretroviral therapy. Neither HCV nor HDV coinfection was shown in any patient. Eighty $(66 \%)$ patients were $\mathrm{HBeAg-negative.}$

Serum HBV-DNA level was detected in all cases, the median value was 15,754 IU/mL (range 68-66,444,954 $\mathrm{IU} / \mathrm{mL})$.

Histological analysis - Among the 82 patients who met the established criteria for liver biopsy, the median of HAI was 4.0 (1-18) and the median of fibrosis stage was 1.5 (1-6). Sixty-eight patients (83\%) had mild inflammation (HAI < 7) and $59(72 \%)$ had mild fibrosis $(<3)$. Liver cirrhosis was observed in $10(12 \%)$ patients.

$H B V$ genotypes - HBV genotypes could be identified by RFLP assay in all patients and five HBV genotypes (A-D, F) were found. Genotype A as the most common, being present in $82(68 \%)$ patients, followed by genotype $\mathrm{F}$ found in 19 (15\%) and genotype D in 17 (14\%). Genotypes $\mathrm{B}$ and $\mathrm{C}$ were rare, identified in only three $(3 \%)$ of the patients who were born in China.

Comparative analysis according to $H B V$ genotypes - Demographic, clinical, biochemical and virological characteristics - Eleven patients were excluded from the comparative analysis: eight receiving antiviral therapy (HBV-HIV), two patients with genotype B and 1 patient

\section{TABLE I}

Demographic, biochemical and virological characteristics of the 121 chronic hepatitis B (HB) patients

$\begin{array}{lc}\text { Male sex [n (\%)] } & 89(74) \\ \text { Mean age (years, SD) } & 38.3 \pm 12.8(12-68) \\ \text { Race [n (\%)] } & \\ \text { White } & 61(50) \\ \text { Black } & 57(47) \\ \text { Asian } & 3(3) \\ \text { Presumed mode of infection [n (\%)] } & \\ \text { Unknown } & 53(44) \\ \text { Sexual or parenteral exposure } & 44(36) \\ \text { Maternal-infant route } & 24(20) \\ \text { Genotype [n (\%)] } & \\ \text { A } & 82(68) \\ \text { B } & 1(1) \\ \text { C } & 2(2) \\ \text { D } & 17(14) \\ \text { F } & 19(15) \\ \text { HBeAg (-) } & 80(66) \\ \text { Elevated ALT } & 62(51) \\ \text { HBV-DNA level (median-IU/mL) } & 15,754(68-66,444,954)\end{array}$

ALT: alanine aminotransferase; HBeAg: HB "e" antigen; HBV: HB virus; SD: standard deviation. 
with genotype $\mathrm{C}$ infection. Thus, 110 patients infected with genotypes A (76), F (18) and D (16) were included in the comparative study. The population's characteristics by genotype are provided in Table II.

In the present study, there was no difference between gender $(p=0.37)$, age $(p=0.78)$, race $(p=0.22)$, presumed mode of infection $(p=0.94)$ and HBV genotypes. As shown in Table II, patients with HBV genotype D were most likely to have lower ALT values $(75 \%)$ compared with genotypes A (47\%) and F (55\%) and these differences were significant $(\mathrm{p}=0.05)$.

There was not significant association between HBV genotypes and the HBeAg status $(p=0.37)$ or HBVDNA levels $(\mathrm{p}=0.47)$.

Histological analysis - Although the large proportion of patients had mild histological changes with minimal liver damage, we observed an association between the inflammation score $(\mathrm{p}=0.001)$ and the fibrosis stage $(\mathrm{p}=$ 0.01 ) with HBV genotypes. Pairwise comparisons showed significant lower scores of inflammation $(\mathrm{HAI}=2)$ and fibrosis (0) in genotype D compared with genotype A $(\mathrm{HAI}=4, \mathrm{p}<0.001 ; \mathrm{F}=2, \mathrm{p}=0.008)$ or genotype $\mathrm{F}$ (HAI $=5, \mathrm{p}=0.009 ; \mathrm{F}=2 \mathrm{p}=0.01$ ), as shown in Table II.

\section{DISCUSSION}

There is growing evidence that HBV genotypes may influence the outcomes and the severity of HBV, mainly in Asian studies, with more serious disease observed in patients infected with genotype C (Lindh et al. 1999, Kao et al. 2000, 2002, Chu et al. 2002, Kobayashi et al.
2002, Sakugawa et al. 2002, Sugauchi et al. 2002, Wai et al. 2002, Chan et al. 2003, Lee et al. 2003, Nakayoshi et al. 2003, Sumi et al. 2003). Nevertheless, the informations about differences in the clinical, virological and histological characteristics among patients with genotypes non-B and non-C, prevailing in Western countries, are scarce and controversial.

Data are conflicting, with some groups reporting severe liver disease in patients with genotype A (Lindh et al. 1996, Mayerat et al. 1999, Kumar et al. 2005, Tonetto et al. 2009) compared with genotype $\mathrm{D}$, while other groups found no significant differences between genotypes A or D, concerning the severity of liver disease, observed in liver specimens (Sanchez-Tapias et al. 2002, Halfon et al. 2006, Madan et al. 2009). The present study is the first to describe less intense histological liver disease in genotype D patients. The clinical significance of genotype A and D and the outcomes of chronic HBV infection remain to be determined so far.

The present study is the largest cross-sectional study that evaluated the clinical significance of HBV genotypes in RJ, the second most populous city in Brazil. In accordance with previous reports (Moraes et al. 1996, Araujo et al. 2004, Ribeiro et al. 2006, Mello et al. 2007, Tonetto et al. 2009), this study showed that HBV genotype A was the most prevalent in RJ, followed by genotypes $\mathrm{D}$ and $\mathrm{F}$. The predominance of genotype A may be the result of the influx of African population during the slavery colonial period and the influence from European immigration that occurred during the 20th century.

\section{TABLE II}

Hepatitis B virus (HBV) genotypes in relation to the demographics, laboratorial and histological characteristics

\begin{tabular}{|c|c|c|c|c|}
\hline & \multicolumn{3}{|c|}{ Genotypes } & \multirow[b]{2}{*}{$\mathrm{p}$} \\
\hline & A & $\mathrm{D}$ & $\mathrm{F}$ & \\
\hline Patient population $(\mathrm{n}=110)[\mathrm{n}(\%)]$ & $76(70)$ & $16(14)$ & $18(16)$ & - \\
\hline Age (mean, SD, years) & $36.9 \pm 13.6$ & $39.1 \pm 11.2$ & $38.5 \pm 11.7$ & $0.78^{a}$ \\
\hline Male sex $[\mathrm{n}(\%)]$ & $57(75)$ & $10(63)$ & $11(61)$ & $0.37^{b}$ \\
\hline \multicolumn{5}{|l|}{ Race $[\mathrm{n}(\%)]$} \\
\hline White & $36(47)$ & $11(69)$ & $11(61)$ & $0.22^{b}$ \\
\hline Presumed mode of infection $[\mathrm{n}(\%)]$ & & & & $0.94^{c}$ \\
\hline Unknown & $35(46)$ & $9(56)$ & $9(50)$ & - \\
\hline Sexual or parenteral exposure & $26(34)$ & $5(31)$ & $5(28)$ & - \\
\hline Maternal-infant route & $15(20)$ & $2(13)$ & $4(22)$ & - \\
\hline $\operatorname{HBeAg}(-)$ & $52(68)$ & $14(88)$ & $13(72)$ & $0.37^{c}$ \\
\hline Normal ALT & $36(47)$ & $12(75)$ & $10(55)$ & $0.13^{b}$ \\
\hline ALT vs. ULN (median, IU/L) & $0.9(0.3-6.6)$ & $0.5(0.3-17.4)$ & $0.9(0.3-3.3)$ & $0.05^{d}$ \\
\hline HBV-DNA level (mean, SD, $\log _{10}$ ) & $4.6 \pm 1.6$ & $4.3 \pm 1.5$ & $4.3 \pm 1.9$ & $0.47^{d}$ \\
\hline \multicolumn{5}{|l|}{ Histology $(\mathrm{n}=82)$} \\
\hline HAI (median) & $4.0(0-11)$ & $2.0(0-7)$ & $5.0(1-8)$ & $0.001^{d}$ \\
\hline Fibrosis (median) & $2.0(0-6)$ & $0(0-5)$ & $2.0(0-3)$ & $0.01^{d}$ \\
\hline Cirrhosis $[\mathrm{n}(\%)]$ & $9(11)$ & $1(1)$ & $0(0)$ & $0.01^{c}$ \\
\hline
\end{tabular}

$a$ : Anova; $b: \chi^{2}$ test; $c$ : Fisher exact test; $d$ : Kruskal Wallis test; ALT: alanine aminotransferase; HAI: histological activity index; HBeAg: HB "e" antigen; HBV: HB virus; SD: standard deviation; ULN: upper limit of normal values. 
An interesting finding was that HBV genotype $\mathrm{F}$ infection, derived from the Amerindian population and the most prevalent in Central and South America, was rare in Brazil, suggesting that indigenous population had less influence in the introduction of HBV in our country (Parana \& Almeida 2005, Viana et al. 2005, Mello et al. 2007).

Contrary to previous studies (Chu et al. 2003, Halfon et al. 2006), we did not find association between race or presumed mode of infection and HBV genotypes. Probably these data may be the result of the great mixtures of races among the Brazilian population, most of whom descendant from European colonizers, African slaves, native indigenous and because our study enrolled patients who were likely infected by sexual or percutaneous exposures in adult age.

In the study from Lindh et al. (2000) a higher proportion of HBeAg-positive patients and higher HBV-DNA levels associated with genotype $\mathrm{D}$ was observed when compared with genotypes A, B and C. In the present study, the majority of patients was $\mathrm{HBeAg}$ negative and the median of HBV-DNA levels was low (below $5 \log _{10}$ $\mathrm{UI} / \mathrm{mL}$ ). In addition, no significant difference was seen between HBV genotypes A, D or F and HBeAg status or HBV-DNA viral load.

There was a significant association between ALT levels and HBV genotypes with lower ALT levels observed in genotype D patients compared with genotypes A and F. Most cross-sectional studies (Thakur et al. 2002, Chu et al. 2003, Gandhe et al. 2003, Kumar et al. 2005, Halfon et al. 2006, Ribeiro et al. 2006, Madan et al. 2009, Tonetto et al. 2009), that have focused on patients with non-B and non-C genotypes, monitored ALT on only one occasion, thus the findings of these studies could not be compared with our results that evaluated ALT levels during a six month period. We acknowledge that patients with chronic HBV may have fluctuating serum ALT and HBV-DNA levels so in the present study we incorporated three determinations of ALT and liver biopsy was a standardized protocol done within the first month after the measurement of HBV-DNA viral load.

In the present study, 82 patients underwent liver biopsy and although a large proportion of patients had mild liver damage, defined when the fibrosis stage was $\leq 2$ and the inflammation grade $\leq 6$, the genotype $\mathrm{D}$ patients were more likely to have significant lower inflammation and fibrosis scores compared with genotype A and $\mathrm{F}$. Thus, our data demonstrated that patients with genotype D infection in RJ had less intense liver damage, with mild necroinflammatory activity and mild fibrosis stage when compared with patients infected with genotypes $\mathrm{A}$ and $\mathrm{F}$.

Otherwise, a frequently reported Indian study, published by Thakur et al. (2002), found more severe liver disease in patients infected with genotype D compared with genotype A. However, in Thakur's study, all patients who underwent liver biopsy had been previously considered for treatment, what may have caused a selection bias (Sanchez-Tapias et al. 2002, Halfon et al. 2006, Madan et al. 2009). In the present study patients with a previous or ongoing treatment were excluded.
In fact, the majority of studies that evaluated the relationship between liver histology and genotypes non-B and non-C did not report the criteria to perform the liver biopsy. One longitudinal study from Spain (SanchezTapias et al. 2002), which compared the clinical outcomes between genotypes A, D and F, could not demonstrate any difference in baseline features, including liver histology, although on prolonged follow-up, patients infected with genotype A had better prognosis than those infected with genotype D.

In the present study the HBV subgenotypes were not evaluated. Regarding genotype A, the most prevalent subgenotype in Brazil is A1 (Mello et al. 2007). So far, it is not known what subgenotypes of genotype D are prevalent in Brazil. The influence of subgenotypes in liver histology is not known and thus, further studies are needed to better clarify this issue.

Since the liver biopsy in the present study was indicated for all patients with either increased HBV-DNA ( $>$ $2,000 \mathrm{IU} / \mathrm{mL}$ ) or ALT levels, the possibility of selection bias is unlikely.

The Southeast Brazil presents a low endemicity of HBV infection. Nevertheless, this is the largest crosssectional study of non-B and non-C genotypes and liver histology in Brazil so far.

In summary, this is the first study to show that HBV genotype $\mathrm{D}$ is associated with less intense liver damage compared with genotypes A and F. Additional studies are needed to better understand these findings and to determine the clinical significance of non-B and non-C genotypes in chronic HBV.

\section{REFERENCES}

Araujo NM, Mello FC, Yoshida CF, Niel C, Gomes SA 2004. High proportion of subgroup A' (genotype A) among Brazilian isolates of Hepatitis B virus. Arch Virol 149: 1383-1395.

Chan HL, Wong ML, Hui AY, Hung LC, Chan FK, Sung JJ 2003. Hepatitis B virus genotype $\mathrm{C}$ takes a more aggressive disease course than hepatitis B virus genotype B in hepatitis B e antigenpositive patients. J Clin Microbiol 41: 1277-1279.

Chu CJ, Hussain M, Lok AS 2002. Hepatitis B virus genotype B is associated with earlier $\mathrm{HBeAg}$ seroconversion compared with hepatitis B virus genotype C. Gastroenterology 122: 1756-1762.

Chu CJ, Keeffe EB, Han SH, Perrillo RP, Min AD, Soldevila-Pico C, Carey W, Brown RS, Jr, Luketic VA, Terrault N, Lok AS 2003. Hepatitis B virus genotypes in the United States: results of a nationwide study. Gastroenterology 125: 444-451.

Gandhe SS, Chadha MS, Arankalle VA 2003. Hepatitis B virus genotypes and serotypes in western India: lack of clinical significance. J Med Virol 69: 324-330.

Halfon P, Bourliere M, Pol S, Benhamou Y, Ouzan D, Rotily M, Khiri H, Renou C, Penaranda G, Saadoun D, Thibault V, Serpaggi J, Varastet M, Tainturier MH, Poynard T, Cacoub P 2006. Multicentre study of hepatitis B virus genotypes in France: correlation with liver fibrosis and hepatitis B e antigen status. J Viral Hepat 13: 329-335.

Ishak K, Baptista A, Bianchi L, Callea F, de Groote J, Gudat F, Denk H, Desmet V, Korb G, MacSween RN 1995. Histological grading and staging of chronic hepatitis. J Hepatol 22: 696-699.

Kao JH, Chen PJ, Lai MY, Chen DS 2000. Hepatitis B genotypes correlate with clinical outcomes in patients with chronic hepatitis B. Gastroenterology 118: 554-559. 
Kao JH, Chen PJ, Lai MY, Chen DS 2002. Genotypes and clinical phenotypes of hepatitis B virus in patients with chronic hepatitis B virus infection. J Clin Microbiol 40: 1207-1209.

Kobayashi M, Arase Y, Ikeda K, Tsubota A, Suzuki Y, Saitoh S, Suzuki F, Akuta N, Someya T, Matsuda M, Sato J, Takagi K, Miyakawa Y, Kumada H 2002. Viral genotypes and response to interferon in patients with acute prolonged hepatitis B virus infection of adulthood in Japan. J Med Virol 68: 522-528.

Kumar A, Kumar SI, Pandey R, Naik S, Aggarwal R 2005. Hepatitis $\mathrm{B}$ virus genotype $\mathrm{A}$ is more often associated with severe liver disease in northern India than is genotype D. Indian J Gastroenterol 24: 19-22.

Lee CM, Chen CH, Lu SN, Tung HD, Chou WJ, Wang JH, Chen TM, Hung $\mathrm{CH}$, Huang CC, Chen WJ 2003. Prevalence and clinical implications of hepatitis B virus genotypes in southern Taiwan. Scand J Gastroenterol 38: 95-101.

Lindh M, Hannoun C, Dhillon AP, Norkrans G, Horal P 1999. Core promoter mutations and genotypes in relation to viral replication and liver damage in East Asian hepatitis B virus carriers. J Infect Dis 179: 775-782.

Lindh M, Horal P, Dhillon AP, Furuta Y, Norkrans G 1996. Hepatitis $\mathrm{B}$ virus carriers without precore mutations in hepatitis B e antigen-negative stage show more severe liver damage. Hepatology 24: 494-501.

Lindh M, Horal P, Dhillon AP, Norkrans G 2000. Hepatitis B virus DNA levels, precore mutations, genotypes and histological activity in chronic hepatitis B. J Viral Hepat 7: 258-267.

Madan K, Batra Y, Sreenivas V, Mizokami M, Tanaka Y, Chalamalasetty SB, Panda SK, Acharya SK 2009. HBV genotypes in India: do they influence disease severity? Hepatol Res 39: 157-163.

Mayerat C, Mantegani A, Frei PC 1999. Does hepatitis B virus (HBV) genotype influence the clinical outcome of $\mathrm{HBV}$ infection? $J \mathrm{Vi-}$ ral Hepat 6: 299-304.

Mello FC, Souto FJ, Nabuco LC, Villela-Nogueira CA, Coelho HS, Franz HC, Saraiva JC, Virgolino HA, Motta-Castro AR, Melo MM, Martins RM, Gomes SA 2007. Hepatitis B virus genotypes circulating in Brazil: molecular characterization of genotype $\mathrm{F}$ isolates. BMC Microbiol 7: 103.

Mizokami M, Nakano T, Orito E, Tanaka Y, Sakugawa H, Mukaide M, Robertson BH 1999. Hepatitis B virus genotype assignment using restriction fragment length polymorphism patterns. FEBS Lett 450: 66-71.

Moraes MT, Gomes SA, Niel C 1996. Sequence analysis of pre-S/S gene of hepatitis B virus strains of genotypes A, D, and F isolated in Brazil. Arch Virol 141: 1767-1773.

Nakayoshi T, Maeshiro T, Nakasone H, Sakugawa H, Kinjo F, Orito E, Mizokami M 2003. Difference in prognosis between patients infected with hepatitis B virus with genotype B and those with genotype $\mathrm{C}$ in the Okinawa Islands: a prospective study. $\mathrm{J} \mathrm{Med}$ Virol 70: 350-354.

Parana R, Almeida D 2005. HBV epidemiology in Latin America. J Clin Virol 34 (Suppl. 1): S130-S133.

Pereira LM, Martelli CM, Merchan-Hamann E, Montarroyos UR, Braga MC, de Lima ML, Cardoso MR, Turchi MD, Costa MA, de Alencar LC, Moreira RC, Figueiredo GM, Ximenes RA 2009. Population-based multicentric survey of hepatitis B infection and risk factor differences among three regions in Brazil. Am J Trop Med Hyg 81: 240-247.

Ribeiro NR, Campos GS, Angelo AL, Braga EL, Santana N, Gomes MM, Pinho JR, De Carvalho WA, Lyra LG, Lyra AC 2006. Distribution of hepatitis B virus genotypes among patients with chronic infection. Liver Int 26: 636-642.

Sakugawa H, Nakasone H, Nakayoshi T, Orito E, Mizokami M, Yamashiro T, Maeshiro T, Kinjo F, Saito A, Miyagi Y 2002. Preponderance of hepatitis $\mathrm{B}$ virus genotype $\mathrm{B}$ contributes to a better prognosis of chronic HBV infection in Okinawa, Japan. $J$ Med Virol 67: 484-489.

Sanchez-Tapias JM, Costa J, Mas A, Bruguera M, Rodes J 2002. Influence of hepatitis B virus genotype on the long-term outcome of chronic hepatitis B in western patients. Gastroenterology 123: $1848-1856$

Sugauchi F, Chutaputti A, Orito E, Kato H, Suzuki S, Ueda R, Mizokami M 2002. Hepatitis B virus genotypes and clinical manifestation among hepatitis B carriers in Thailand. J Gastroenterol Hepatol 17: 671-676.

Sumi H, Yokosuka O, Seki N, Arai M, Imazeki F, Kurihara T, Kanda T, Fukai K, Kato M, Saisho H 2003. Influence of hepatitis B virus genotypes on the progression of chronic type B liver disease. Hepatology 37: 19-26.

Thakur V, Guptan RC, Kazim SN, Malhotra V, Sarin SK 2002. Profile, spectrum and significance of HBV genotypes in chronic liver disease patients in the Indian subcontinent. $J$ Gastroenterol Hepatol 17: 165-170.

Tonetto PA, Goncales NS, Fais VC, Vigani AG, Goncales ES, Feltrin A, Goncales FL 2009. Hepatitis B virus: molecular genotypes and $\mathrm{HBeAg}$ serological status among $\mathrm{HBV}$-infected patients in the southeast of Brazil. BMC Infect Dis 9: 149.

Viana S, Parana R, Moreira RC, Compri AP, Macedo V 2005. High prevalence of hepatitis B virus and hepatitis D virus in the western Brazilian Amazon. Am J Trop Med Hyg 73: 808-814.

Wai CT, Chu CJ, Hussain M, Lok AS 2002. HBV genotype B is associated with better response to interferon therapy in $\mathrm{HBeAg}(+)$ chronic hepatitis than genotype C. Hepatology 36: 1425-1430.

WHO - World Health Organization 2000. Hepatitis B. Fact sheet 204. Available from: who.int/mediacentre/factsheets/fs204/en/. 